\title{
Follow-up strategy with long-term veno-venous extracorporeal membrane oxygenation support for complicated severe acute respiratory distress related to COVID-19 and recovery of the lungs
}

\author{
COVID-19 enfeksiyonuna bağlı komplike şiddetli akut respiratuvar distres sendromunda \\ uzun dönem venovenöz ekstrakorporeal membran oksijenasyon desteği ile \\ takip stratejisi ve akciğerlerin iyileşme süreci
}

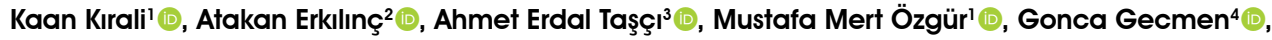

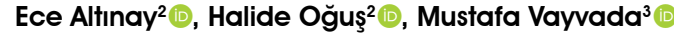 \\ Institution where the research was done: \\ Kartal Koșuyolu High Specialization Education and Research Hospital, Istanbul, Turkey
}

Author Affiliations:

'Department of Cardiovascular Surgery, Kartal Koșuyolu High Specialization Education and Research Hospital, Istanbul, Turkey 2Department of Anesthesiology and Reanimation, Kartal Koşuyolu High Specialization Education and Research Hospital, Istanbul, Turkey ${ }^{3}$ Department of Thoracic Surgery, Kartal Koșuyolu High Specialization Education and Research Hospital, Istanbul, Turkey ${ }^{4}$ Department of Pathology, Kartal Lütfi Kırdar City Hospital, Istanbul, Turkey

\begin{abstract}
Novel coronavirus-2019 (COVID-19) pandemic has affected all over the world, leading to viral pneumonia-complicating severe acute respiratory distress syndrome and death. Although there is no proven definitive treatment yet, physicians use some assistive methods based on the previous epidemic viral acute respiratory distress syndrome experiences. Extracorporeal membrane oxygenation is one of them. In this report, we present one of the longest survived extracorporeal membrane oxygenation case (71 days) with COVID-19 infection and the pathology of the infected lung, with our veno-venous extracorporeal membrane oxygenation strategy.
\end{abstract}

Keywords: Acute respiratory distress syndrome, COVID-19, COVID-19 pathology. extracorporeal membrane oxygenation, veno-venous.

Clinical findings of novel coronavirus-2019 (COVID-19) infection range from mild symptoms such as asymptomatic disease or mild upper respiratory tract infection to severe viral pneumonia accompanied by respiratory failure or multiorgan dysfunction syndrome, which can be fatal. ${ }^{[1-4]}$

\section{$\ddot{O} Z$}

Yeni koronavirüs-2019 (COVID-19) pandemisi, viral pnömoniye bağl1 şiddetli akut respiratuvar distres sendromu ve ölüme yol açarak, tüm dünyayı etkisi altına almıştır. Henüz kanıtlanmış kesin bir tedavi olmamasına rağmen, hekimler önceki epidemik viral akut respiratuvar distres sendromu deneyimlerinden faydalanarak, bazı yardımcı yöntemler kullanmaktadır. Ekstrakorporeal membran oksijenasyonu da bunlardan biridir. $\mathrm{Bu}$ makalede, COVID-19 enfeksiyonu ile hayatta kalan en uzun ekstrakorporeal membran oksijenasyonu olgularından biri (71 gün) ve enfekte akciğer patolojisi, veno-venöz ekstrakorporeal membran oksijenasyon stratejimiz ile birlikte sunuldu.

Anahtar sözcükler: Akut respiratuvar distres sendromu, COVID-19, COVID-19 patolojisi, ekstrakorporeal membran oksijenasyonu, venovenöz.

A staged support strategy for hospitalized COVID-19-related acute respiratory distress syndrome (ARDS) patients is proposed by Koşuyolu team to treat, to survive, and to recovery. Stage 1 (medical therapy) with mild, non-specific ARDS (pre-ARDS) symptoms such as cough, weakness,

Received: December 08, 2020 Accepted: February 21, 2021 Published online: April 26, 202

Correspondence: Kaan Kırali, MD. Kartal Koşuyolu Yüksek İhtisas Eğitim ve Araştırma Hastanesi, Kalp ve Damar Cerrahisi Kliniği, 34865 Kartal, İstanbul, Türkiye. Tel: +90 532 - 6140254 e-mail: imkbkirali@yahoo.com 
and dyspnea require only non-invasive positivepressure ventilation (NIPPV) support (high-flow nasal oxygen [HFNO], continuous positive airway pressure [CPAP], and bilevel positive airway pressure [BiPAP]) with/without awake prone position in the early period to prevent spontaneously breathing and to avoid endotracheal intubation. Stage 2 (advanced therapy) patients with worsening of respiratory mechanics, respiratory acidosis, and mental status due to deepening hypoxemia, resulting from exacerbation of mild ARDS to moderate and requiring invasive mechanical ventilation (IMV) support. The management of IMV depends on the phenotype of COVID-19-related pneumonia: Type 1 phenotype ARDS (non-typical ARDS) associated with normal pulmonary compliance $\left(>50 \mathrm{~mL} / \mathrm{cmH}_{2} \mathrm{O}\right)$ and low lung elastance-weight-recruitability, leading to a large ventilation/perfusion mismatch, should be treated with the standard IMV approach with Pressure Control/Pressure Support (PC/PS) to improve the ventilation/perfusion mismatch by prevented tidal volume (TV) 6 to $8 \mathrm{~mL} / \mathrm{kg} / \mathrm{breath}$, avoiding atelectasis via a limited positive end-expiratory pressure (PEEP) level of $<8 \mathrm{cmH}_{2} \mathrm{O}$ and keeping the respiratory rate at $<20$ breaths/min. Type 2 phenotype ARDS (typical ARDS) with decreased pulmonary compliance $\left(<40 \mathrm{~mL} / \mathrm{cmH}_{2} \mathrm{O}\right)$ and high lung elastance-weight-recruitability, leading to pulmonary infiltration, should be treated with the lung protective IMV approach with PC/PS-mode to reduce lung and vascular stress by liberalized TV between 4 to $6 \mathrm{~mL} / \mathrm{kg} /$ breath, PEEP $<10 \mathrm{cmH}_{2} \mathrm{O}$, plateau pressure (PP) $<30 \quad \mathrm{cmH}_{2} \mathrm{O}$, and peak inspiratory pressure (PIP) $<20 \mathrm{mmHg}$, and by increased fraction of inspired oxygen $\left(\mathrm{FiO}_{2}\right)$ level, ensuring adequate tissue oxygenation. Stage 3 (rescue therapy) patients with refractory hypoxemia (partial pressure of oxygen $\left[\mathrm{PaO}_{2}\right] / \mathrm{FiO}_{2}$ ratio $<80 \mathrm{mmHg}$ for $>6 \mathrm{~h}$, or $\mathrm{PaO}_{2} / \mathrm{FiO}_{2}$ ratio $<50 \mathrm{mmHg}$ for $>3 \mathrm{~h})$ and hypercarbia $(\mathrm{pH}<7.25$ and partial pressure of carbon dioxide $\left[\mathrm{PaCO}_{2}\right]>65 \mathrm{mmHg}$ ) due to aggravation of ARDS (atypical ARDS), need additional gas exchange support via veno-venous extracorporeal membrane oxygenation (vv-ECMO) to improve tissue perfusion and carbon dioxide $\left(\mathrm{CO}_{2}\right)$ removal, and also to nullify lungs and take them under protection. Stage 4 (recovery therapy) patients supported with vv-ECMO against destructive COVID-19-related ARDS should be kept alive for the whole course first to salvage and, then, to recover lungs and respiratory functions (recovered ARDS), combining with a very protective IMV approach via PC/PS mode with lowest pressure levels
(PEEP $<8 \mathrm{cmH}_{2} \mathrm{O}, \mathrm{PP}<25 \mathrm{cmH}_{2} \mathrm{O}$, PIP $\leq 15 \mathrm{cmH}_{2} \mathrm{O}$ ) and lower oxygen supply (ventilator $\mathrm{FiO}_{2}=50 \%$ ) regardless of TV values in every breath and min, which can drop as low as $1 \mathrm{~mL} / \mathrm{kg} / \mathrm{breath}$.

In this report, we describe our longer vv-ECMO support strategy, showing how we kept the patient alive for 71 days on vv-ECMO, and how he is still survived after weaning form vv-ECMO support. This patient is also the first alive case worldwide to show the ability of failed lungs to recover over time and to demonstrate microscopically histopathological findings of COVID-19 infection in the lungs.

\section{CASE REPORT}

\section{Clinical course before referral to our hospital}

A 44-year-old male patient, complaining of malaise and weakness, was admitted to a private medical center and treated for an upper respiratory tract infection in the outpatient setting on April $2^{\text {nd }}, 2020$. However, he applied to another medical center again due to symptoms exacerbated by shortness of breath and fatigue two days later and was diagnosed with pneumonia. Medications were arranged and home rest was recommended. On April $6^{\text {th }}$, on the onset of high fever and cough complaints, he was referred to a large-volume medical center and he was diagnosed with COVID-19 infection. As his arterial oxygen saturation $\left(\mathrm{SaO}_{2}\right)$ on the pulse oximeter was $98 \%$ and he had no findings of dyspnea or shortness of breath, he was discharged to home quarantine, after the antiviral COVID-19 medication with hydroxychloroquine and favipiravir was arranged. On April $9^{\text {th }}$, he was referred with shortness of breath, fever, and fatigue to a research hospital, and he was hospitalized with $\mathrm{SaO}_{2}$ 94\%. Azithromycin and ceftriaxone treatments were added. On the following days, his clinical condition was deteriorated and pulse oxygen saturation $\left(\mathrm{SpO}_{2}\right)$ value lowered progressively (88 to 90\%) under HFNO with $6 \mathrm{~L} / \mathrm{min}$ oxygen support. The chest X-ray revealed progression of bilateral extensive infiltration (Figure 1). Ten days after the first symptoms, he was taken to the intensive care unit (ICU) due to severe hypoxemia $\left(\mathrm{SaO}_{2} 85 \%\right)$ and higher respiratory rate 45 , and IMV was initiated immediately. The ventilatory mode was set to pressure support mode with parameters of PIP $24 \mathrm{cmH}_{2} \mathrm{O}$, PEEP $10 \mathrm{cmH}_{2} \mathrm{O}, \mathrm{FiO}_{2} 80 \%$, respiratory rate $16 / \mathrm{min}$, and $\mathrm{SaO}_{2}$ increased to $98 \%$ with this maneuver. His chest computed tomography revealed extensive bilateral ground glass opacities. As no clinical improvement was observed, the patient was positioned to prone position, but this maneuver could not be enough to cure severe hypoxia. In addition to his medications, immune 

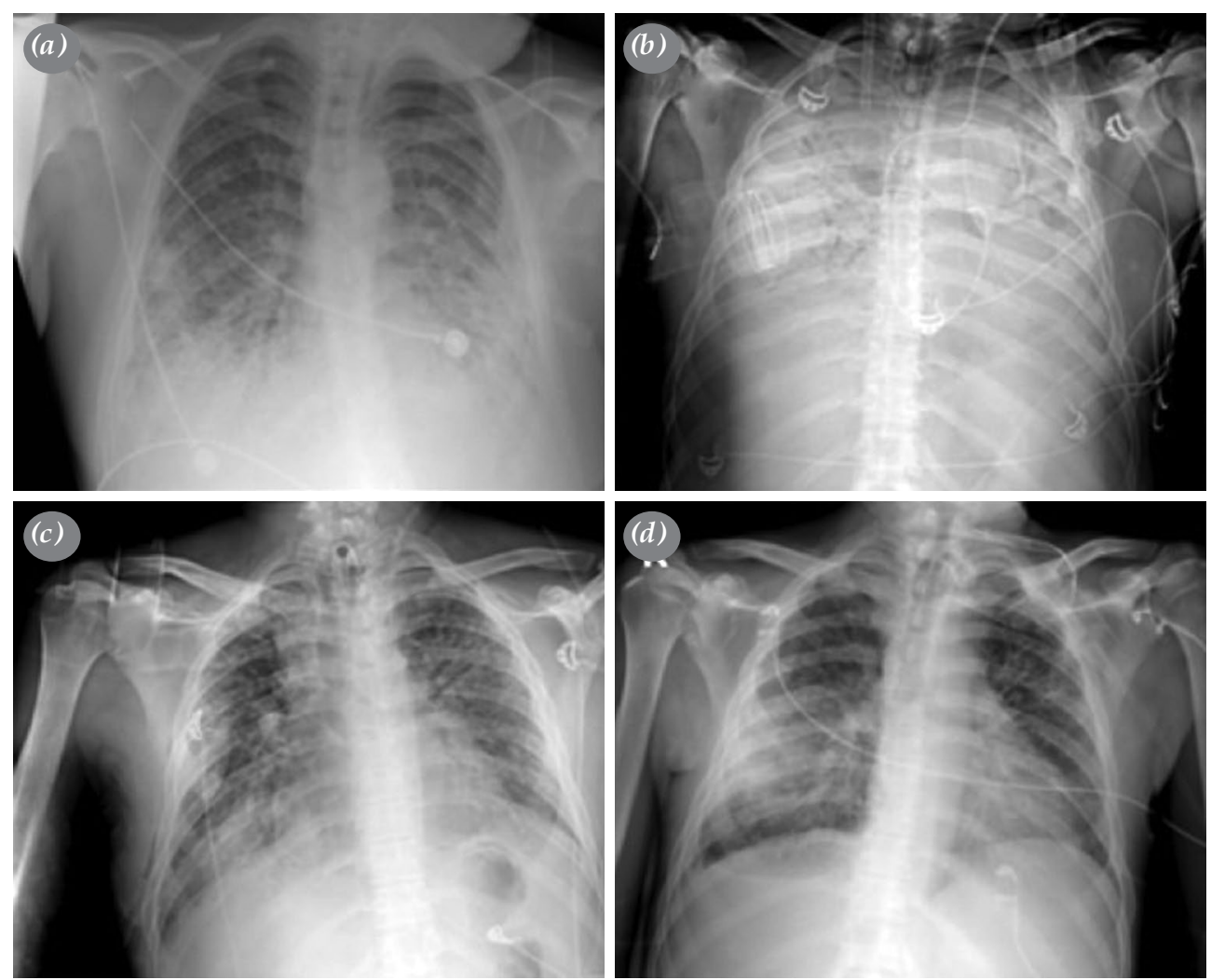

Figure 1. Chest X-rays (a) before endotracheal intubation with diffuse infiltrations; (b) at the end of first month on vv-ECMO, diffuse infection with bacterial infection; (c) after weaning from 71 days vv-ECMO, regression of the opacities; (d) after five months, discharge from ICU.

vv-ECMO: Veno-venous extracorporeal membrane oxygenation; ICU: Intensive care unit.

plasma treatment was given on April $19^{\text {th }}$. Despite medical treatment, therapeutic approaches, and optimal ventilatory support, the patients' clinical condition was worsened as assessed by the arterial blood gas analysis (pH 7.24, $\mathrm{SaO}_{2} 87 \%, \mathrm{PO}_{2} 63 \mathrm{mmHg}, \mathrm{PCO}_{2} 108 \mathrm{mmHg}$ ), and the patient was consulted to our ECMO team and we decided to perform vv-ECMO support.

\section{ECMO-Course in our hospital}

After he was transferred from an external center to our ICU on April $26^{\text {th }}$, we implanted vv-ECMO immediately. The right internal jugular vein was cannulated with a 19-Fr heparin-coated cannula for blood return, and the right femoral vein was cannulated with a 23-Fr heparin-coated cannula for blood drainage. Both cannula placements were evaluated under transthoracic echocardiography and chest X-ray for possible re-circulation. We also placed a pulmonary catheter through the left jugular vein to evaluate the mixed venous $\left(\mathrm{SvO}_{2}\right)$, or pulmonary artery oxygen saturation $\left(\mathrm{SpaO}_{2}\right)$, showing also pulmonary arterial $\mathrm{O}_{2}$ and $\mathrm{CO}_{2}$ values. The anticoagulation protocol was provided with bivalirudin infusion to keep an active partial thromboplastin time of $>50 \mathrm{sec}$ and active clotting time of $>160 \mathrm{sec}$. Daily blood samples were taken from four lines twice a daily: before and after oxygenator, arterial line, and pulmonary catheter. We attempted to keep the ECMO flow at maximum $(>6 \mathrm{~L} / \mathrm{min}$ ) to maintain adequate oxygenation and to prevent hypercarbia. The ventilatory mode was set to PS/PC-mode with the standard approach, but we decreased them with time to acceptable lowest level of PIP (15 to $\left.18 \mathrm{cmH}_{2} \mathrm{O}\right)$, PEEP $\left(<8 \mathrm{cmH}_{2} \mathrm{O}\right)$ and $\mathrm{PP}\left(<25 \mathrm{cmH}_{2} \mathrm{O}\right)$ with $\mathrm{FiO}_{2} 50 \%$. Adjustment of ventilatory and ECMO parameters was made to target levels $\mathrm{SpaO}_{2}>90 \%$ and $\mathrm{SaO}_{2}>90 \%$. The course of vv-ECMO and mechanical ventilation parameters before, during, and after ECMO support are given in daily graphics (Figure 2).

With the ECMO support, $\mathrm{SpaO}_{2}$ and $\mathrm{SaO}_{2}$ levels improved and severe hypoxemia resolved, increasing tissue perfusion, and $\mathrm{PCO}_{2}$ decreased dramatically, eliminating respiratory acidosis. Although his last two polymerase chain reaction (PCR) test results were 


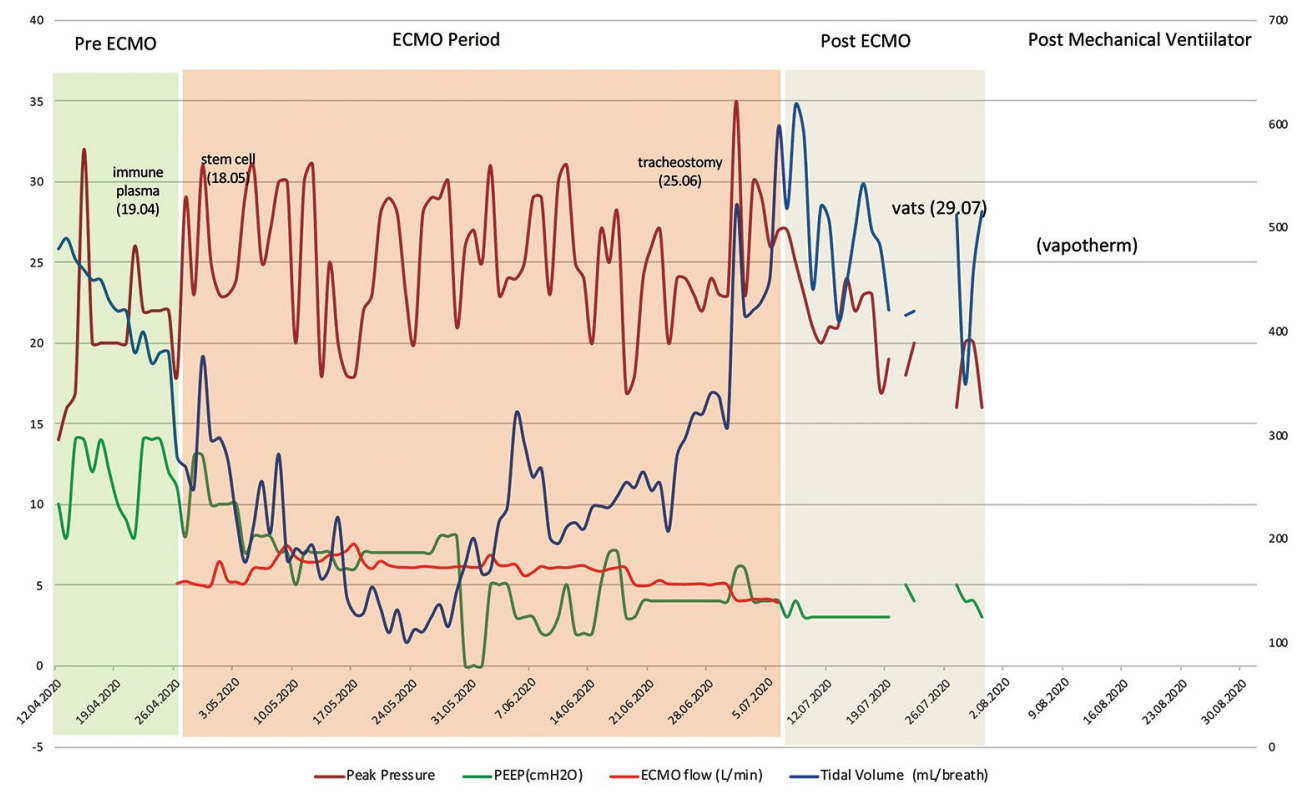

Figure 2. Ventilatory and ECMO parameters during follow-up.

ECMO: Extracorporeal membrane oxygenation.

negative, there were several infection attacks with different pathogens such as Acinetobacter Baumannii, Klebsiella pneumoniae, and Clebsiella Pneumonia, Candida spp., and all of them were treated with wide spectrum antibiotics and antifungals. On May $18^{\text {th }}$, mesenchymal stem cell therapy was applied for three times (the first two intravenously through Swan-Ganz catheter and the last intratracheally through endotracheal tube). During follow-up, we sustained all ventilatory pressure supports at the lowest values to keep both lungs in rest. The total respiratory TV decreased until $70 \mathrm{~mL} /$ breath and total TV until

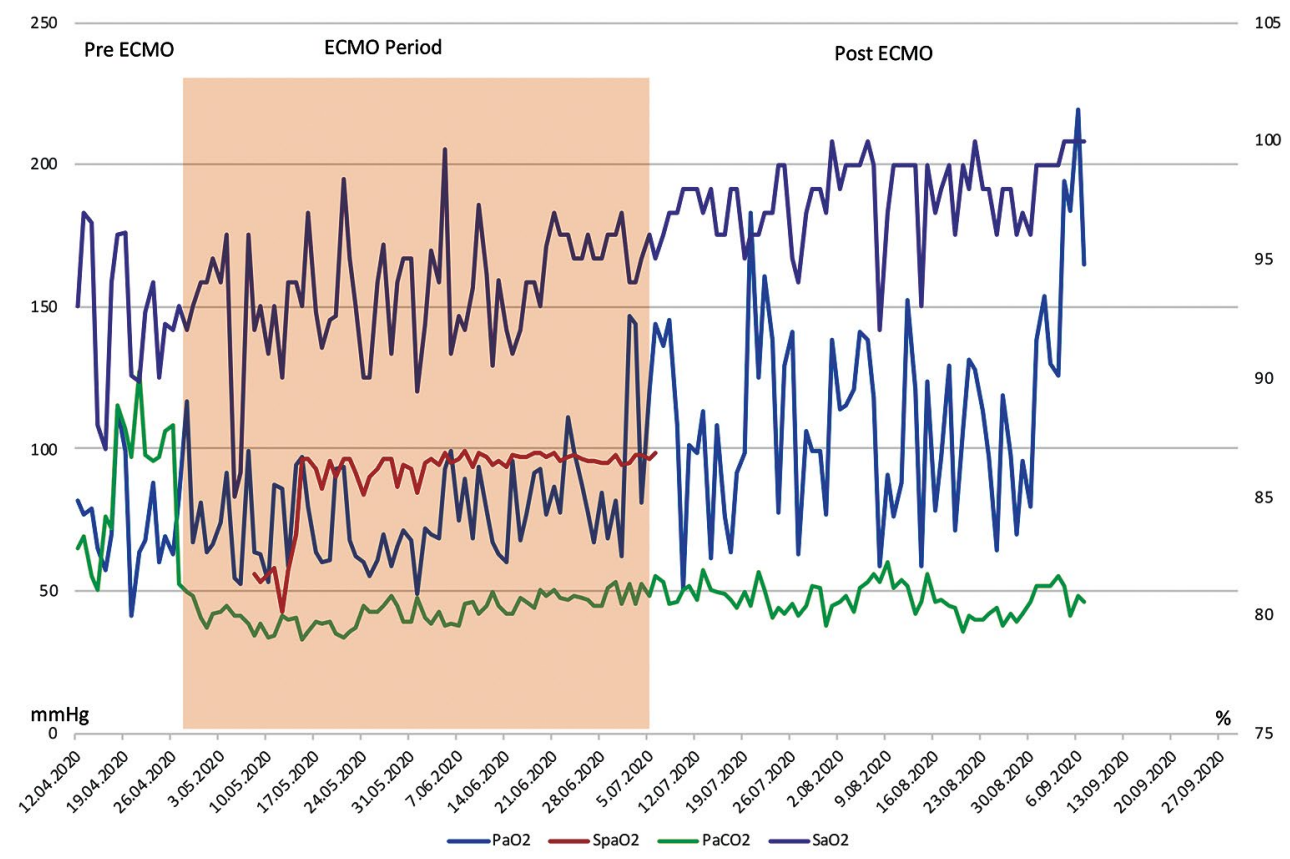

Figure 3. Blood gas analyses during follow-up.

ECMO: Extracorporeal membrane oxygenation. 
2.5 to $3 \mathrm{~L} / \mathrm{min}$ independent from the ventilatory mode's parts PS/PC.

\section{ECMO-Wean protocol}

During the course, active infection resolved and we observed a mild improvement on chest X-ray and also in TV (without changing the PEEP) day by day at the beginning of June. Although TV reached $200 \mathrm{~mL} /$ breath according to blood gas analyses and chest X-ray, we thought that it was still not enough for ECMO weaning and kept full support. Eventually at the second half of the June, we observed a dramatic improvement on chest X-ray and also at TV (reaching above $300 \mathrm{~mL} /$ breath) and ameliorating blood gas analyses (Figure 3). On June $25^{\text {th }}$, the tracheostomy was performed to avoid complications of endotracheal intubation and to ensure oral nutrition, as well as to cease deep anesthesia and to wake him. Meanwhile, we decided him to wean from the ECMO due to reduced extensive infiltration on chest X-ray and ameliorating blood gas analyses via IMV. We started to reduce ECMO flow to $5 \mathrm{~L} / \mathrm{min}$ for three days and, then, to $4 \mathrm{~L} / \mathrm{min}$ and reduced the ECMO $\mathrm{FiO}_{2} 10 \%$ everyday according to patient's clinical status and blood gas analyses. However, on July $2^{\text {nd }}$, the patient had pneumothorax of the right hemithorax and we performed a tube thoracostomy and keep the flow at $5 \mathrm{~L} / \mathrm{min}$ for possible deterioration. Eventually on July $6^{\text {th }}$, upon the recovery of respiratory functions, ECMO was weaned 72 days after initial support.

\section{Respiratory recovery course}

We followed the patient on mechanical ventilator after 12-day decannulation period. After decannulation from ECMO, respiratory parameters and blood gas analyses were stable for the patient (TV $>400 \mathrm{~mL} /$ breath). We started to mobilize the patient beginning with rolling than sitting after the cannulation. During follow-up, there was an opacity in the right hemithorax. Chest ultrasound showed fluid accumulation and TV decreased below $500 \mathrm{~mL} /$ breath. On June $21^{\text {st }}$, we performed needle thoracentesis of $750 \mathrm{~mL}$ serous fluid from the right hemithorax via ultrasonography guidance. Opacity on chest X-ray was recovered; however, during followup, the opacity appeared again. On July $12^{\text {th }}$, we decided to perform video-assisted thoracoscopy surgery (VATS) procedure to the right hemithorax. There was an empyema thoracis and decortication, and wedge resection was performed. Decortication was performed for empyema thoracis and wedge resection was performed to evaluate the lung tissue. After VATS procedure, the need for the mechanical ventilation support was reduced and we applied CPAP mode for preparing to separate the patient from IMV. We followed the patient at CPAP mode for one day and observed that all the parameters were stable. Eventually on July $18^{\text {th }}$, we completely weaned the patient from mechanical ventilator. We followed the patient with $2 \mathrm{~L} / \mathrm{min}$ oxygen therapy in the ICU for two
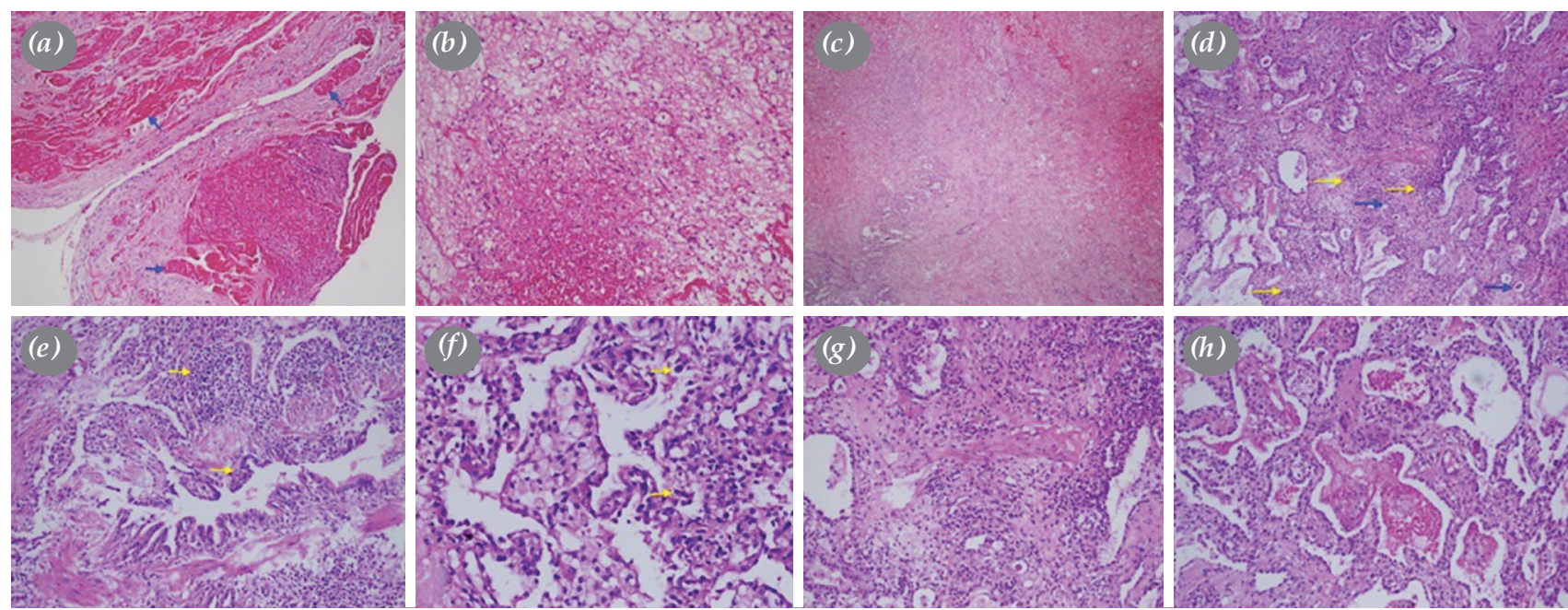
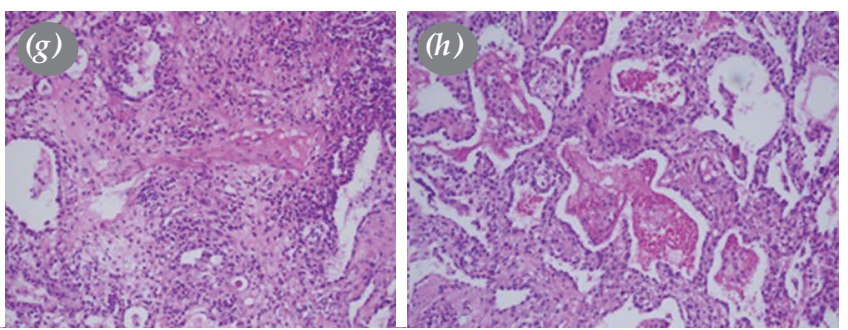

Figure 4. Histopathological findings revealing pleuritis and pneumonitis. (a) Pleuritis exhibited fibrinous exudates (blue arrows) on visceral pleural surfaces. (b) Organizing by a wide granulation tissue. (c) Fibroblasts in organizing areas. (d) Other histopathological findings in lung biopsy revealed infectious interstitial pneumonia which exhibited alveolar walls infiltrated with mononuclear cells (yellow arrows), predominantly lymphocytes, macrophages and plasma cells, and small protein globules (blue arrows) in the alveolar spaces. (e) The bronchioles had lymphocytes (yellow arrows) in the walls of bronchioles and peribronchial areas. (f) Type II pneumocyte hyperplasia (yellow arrows) consistent with an early diffuse alveolar damage pattern. (g) High power showed fibroblasts in the alveolar walls. (h) Finally, intraalveolar fibrin and macrophages were revealed. 
days for any possible deterioration. After observing clinically stable parameters, we transferred the patient to the ward. He received respiratory physiotherapy and extremity physiotherapy. He started to walk and feed by himself. Finally, we removed the tracheostomy cannula and cease the $\mathrm{O}_{2}$ therapy and discharged the patient.

\section{Histopathological findings}

The right middle lobe wedge resection specimen was fixed in $10 \%$ neutral buffered formalin and was sent to the pathology laboratory. On gross examination, the thickening of the pleura and edematous lung parenchyma was observed. The piece was painted with hematoxylin and eosin (H-E) and, then, stained sections were analyzed. The findings were compatible with atypical pneumonia primarily involving the pulmonary interstitium, small airways, and alveolar spaces. Microscopic examination of the lung showed a wide area of architecturally preserved parenchyma with pleuritis and interstitial thickening due to mononuclear cell infiltration.

Histopathological findings revealed pleuritis that exhibited fibrinous exudates on the visceral pleural surfaces, which were organized by a wide granulation tissue (Figure 4). The pathological changes in the bronchioles included lymphohistiocytic cell-mediated inflammatory responses. In H-E-stained sections, there was lymphocytes in the walls of bronchioles and peribronchial areas. Other histopathological finding revealed non-specific infectious interstitial pneumonia which exhibited alveolar walls infiltrated with mononuclear cells, predominantly lymphocytes, macrophages and plasma cells consistent with early diffuse alveolar damage pattern, as type II pneumocyte hyperplasia. Due to diffuse alveolar damage caused by viruses as the most common infectious pathogen, we carefully examined the evidence of virus-induced cytopathic changes. The absence of the nuclear cytopathic changes did not exclude a viral etiology. High power showed fibroblasts in the alveolar walls. There was no neutrophilic inflammation observed most frequently as the manifestation of a superimposed bacterial pneumonia. The reparative process in response to acute airway injury could include squamous metaplasia of the respiratory surfaces; however, our case did not reveal squamous metaplasia. Finally, intraalveolar fibrin and macrophages were revealed. There was no evidence of vasculitis and endotheliitis.

A written informed consent was obtained from the legal representatives and/or guardians of the patient for all diagnostic and therapeutic procedures.

\section{DISCUSSION}

The COVID-19 mainly affects the respiratory system and causes ARDS ranging from mild to severe degree, in which the last resort may be vv-ECMO to improve severe hypoxemia and hypercarbia, allowing lung rest at minimal ventilator settings to prevent further lung injury due to high pressures and oxygen settings. Although there are several different approaches to timing and suitability assessment for vv-ECMO implementation, the use of $\mathrm{vv}$-ECMO has not become widespread worldwide for COVID-19-related ARDS due to controversial results. ${ }^{[5-7]}$ In our institution, criteria of initiating $\mathrm{vv}$-ECMO to rescue injured lungs in severe ARDS are very simple, as well as not delaying the process. First of all, we prefer to avoid IMV, compared to spontaneous breathing with/without NIPPV, and vV-ECMO support, compared to IMV, as much as possible. If every maneuver fails to improve patient condition, we do not delay vv-ECMO implementation. The criteria for vv-ECMO support in patients treated with maximal ventilatory arrangement (PEEP 8 to $10 \mathrm{cmH}_{2} \mathrm{O}$, $\mathrm{FiO}_{2} \quad 100 \%$, PIP 20-25 $\mathrm{cmH}_{2} \mathrm{O}$ ) are persistent hypoxemia $\left(\mathrm{PaO}_{2}<50 \mathrm{mmHg}\right.$ for $6 \mathrm{~h}$ or $\mathrm{PaCO}_{2}>80$ $\mathrm{mmHg}$ ), respiratory acidosis $(\mathrm{pH}<7.25)$, decreased TV $(<2 \mathrm{~mL} / \mathrm{kg})$, reduced pulmonary compliance ( $\left.\mathrm{PP}>30 \mathrm{cmH}_{2} \mathrm{O}\right)$, and circulatory collapse.

After vv-ECMO support is installed, the protective lung ventilation settings should be regulated in PS/PC-mode (PEEP $5 \mathrm{cmH}_{2} \mathrm{O}$, PIP <20 $\mathrm{cmH}_{2} \mathrm{O}$, PP $<25 \mathrm{cmH}_{2} \mathrm{O}, \mathrm{FiO}_{2} 50 \%$ ) with optimized respiratory rate $(<15 \mathrm{breath} / \mathrm{min})$ and supported with keeping airways free of secretion by closed suction circuit and/or bronchoscopy. The body oxygenation and decarboxylation should be managed via vv-ECMO to keep $\mathrm{PaO}_{2}>60 \mathrm{mmHg}$ (ideally $>80 \mathrm{mmHg}$ ) and $\mathrm{PaCO}_{2}<60 \mathrm{mmHg}$ (ideally $<50 \mathrm{mmHg}$ ). Patients may need to be sedated during this period. Femoro-jugular configuration is the most efficient technique and allows lower recirculation rate than the other configurations. ${ }^{[8]}$ The outflow cannula must be placed at the vena superior cava-atrial junction and inflow cannula should be placed below the diaphragm with a minimum distance of $15 \mathrm{~cm}$ between the two cannula ostia to avoid recirculation and insufficient extracorporeal oxygenation. The output of ECMO should be increased as much as possible, preferably close to cardiac output, to ensure adequate body perfusion, supporting by highest $\mathrm{FiO}_{2}$ for oxygenation and lowest fresh gas flow for decarboxylation. A Swan-Ganz catheter should be placed in the main pulmonary artery to monitor 
the competence of gas exchange via vv-ECMO. Anticoagulation must be provided and maintained preferably with bivalirudin rather than heparin, preventing heparin-induced thrombocytopenia. On the other hand, ECMO lines eliminate the need for new intravenous lines for hemofiltration, cytokine filtration or plasmapheresis.

The aim of vV-ECMO in COVID-19-related ARDS is to prevent life-threatening hypoxemia and hypercarbia as a rescue therapy, as well as to survive patient lungs as a recovery therapy. Lungs become more rigid with time and the lung-rest IMV is essential to prevent complete lung collapse and to keep lungs open, resulting in extremely small TVs that cannot lead to effective gas exchange in many patients. Once the patient is stabilized, some spontaneous breathing activity may be allowed to exercise the respiratory muscles. Tracheostomy is performed as earlier as possible to prevent endotracheal intubation-related complications and restrictions. The most important indicator for the improved gas-exchange resulting from the lungs are pulmonary compliance and TV, signaling the starting of recovery of the lungs. Gas exchange improves with the increased inspiratory $\mathrm{TV}$ that indirectly starts weaning from ECMO, as well as from IMV in the next stage. The differences in weaning strategies for vv-ECMO are based on clinical experience. In our clinic, after the TV starts to improve, we reduce first ECMO $\mathrm{FiO}_{2}$ and the sweep gas according to the daily assessment of blood gas values. We do not prefer increasing the IMV setting during weaning. When ECMO $\mathrm{FiO}_{2}$ decreases to $<60 \%$, we begin to reduce the ECMO flow to half and, then, we reduce $\mathrm{FiO}_{2}$ to $21 \%$ step by step. The last step before ECMO decannulation consists of the lowest ECMO settings (flow $<2 \mathrm{~L} / \mathrm{min} ; \mathrm{FiO}_{2}<21 \%$; sweep gas at $0 \mathrm{~L} / \mathrm{min}$ ) and ventilatory settings ( $\mathrm{TV}>4 \mathrm{~mL} / \mathrm{kg} / \mathrm{breath}$; PP $<30 \mathrm{cmH}_{2} \mathrm{O} ; \mathrm{PEEP}<8 \mathrm{cmH}_{2} \mathrm{O} ; \mathrm{FiO}_{2}<50 \%$ ) with an adequate body oxygenation $\left(\mathrm{SaO}_{2}>95 \%\right)$.

In conclusion, vv-ECMO may be a life-saving support option in the presence of pandemic ARDS. According to the report by the Extracorporeal Life
Support Organization (ELSO) Registry in September $2020^{[6]}$ stating a mortality and survival rate of $<40 \%$ in patients treated with ECMO, the strict recommendation for the treatment of refractory COVID-19-related ARDS is to refer patients to specialized centers for vv-ECMO support.

\section{Declaration of conflicting interests}

The authors declared no conflicts of interest with respect to the authorship and/or publication of this article.

\section{Funding}

The authors received no financial support for the research and/or authorship of this article.

\section{REFERENCES}

1. Zhou F, Yu T, Du R, Fan G, Liu Y, Liu Z, et al. Clinical course and risk factors for mortality of adult inpatients with COVID-19 in Wuhan, China: A retrospective cohort study. Lancet 2020;395:1054-62.

2. Navas-Blanco JR, Dudaryk R. Management of respiratory distress syndrome due to COVID-19 infection. BMC Anesthesiol 2020;20:177.

3. Baksh M, Ravat V, Zaidi A, Patel RS. A systematic review of cases of acute respiratory distress syndrome in the Coronavirus disease 2019 pandemic. Cureus 2020;12:e8188.

4. Tzotzos SJ, Fischer B, Fischer H, Zeitlinger M. Incidence of ARDS and outcomes in hospitalized patients with COVID-19: A global literature survey. Crit Care 2020;24:516.

5. Cho HJ, Heinsar S, Jeong IS, Shekar K, Li Bassi G, Jung JS, et al. ECMO use in COVID-19: Lessons from past respiratory virus outbreaks-a narrative review. Crit Care 2020;24:301.

6. Barbaro RP, MacLaren G, Boonstra PS, Iwashyna TJ, Slutsky AS, Fan E, et al. Extracorporeal membrane oxygenation support in COVID-19: An international cohort study of the Extracorporeal Life Support Organization registry. Lancet 2020;396:1071-8.

7. Lentz S, Roginski MA, Montrief T, Ramzy M, Gottlieb M, Long B. Initial emergency department mechanical ventilation strategies for COVID-19 hypoxemic respiratory failure and ARDS. Am J Emerg Med 2020;38:2194-202.

8. Fiore A, de Roux Q, Daami N, Clariot S, Folliguet T, Taccone FS, et al. Clinical feedback from experience with COVID-19: Specific considerations for extracorporeal membrane oxygenation. J Infect 2020;81:e59-e60. 